\title{
Gender and experiences of retaliation
}

\section{Gênero e experiências de retaliação}

Kely César Martins de Paiva

Federal University of Minas Gerais (UFMG), Avenida Antônio Carlos, 6627, Campus Pampulha, 31270-901, Belo Horizonte, MG, Brasil, kelypaiva@face.ufmg.br

Hélio Arthur Reis Irigaray

Fundação Getúlio Vargas, Brazil, helio.irigaray@fgv.br

Mariana Branquinho Macedo

Federal University of Minas Gerais (UFMG), Brazil, maribma17@gmail.com

Jesuína Maria Pereira Ferreira

Federal University of Minas Gerais (UFMG), Brazil, jesuinna@gmail.com

Gizelle Souza Mageste

Federal University of Minas Gerais (UFMG), Brazil, gizellemageste@gmail.com

Michelle Regina Santana Dutra

Centro Universitário de Belo Horizonte (Uni BH), Brazil, michelle.dutra@prof.unibh.br

\section{Abstract}

Given the idiosyncrasies of call center work, its impact on the lives of employees and their possible reactions, we analyzed what forms of retaliation can occur in such an environment by considering gender. We performed qualitative descriptive research. We have interviewed 20 call center agents ( 9 men and 11 women) in Belo Horizonte, the capital city of Minas Gerais state, in Brazil. We fully transcribed all interviews and subjected the data to discourse analysis (the French approach). The results showed that in this case, there was no gender difference regarding perceived unfairness. Thus, workers of both genders often retaliate and consider their actions to be reasonable.

Keywords: Retaliation, gender, call center.

\section{Resumo}

Dadas as idiossincrasias do trabalho do call center, seu impacto na vida dos funcionários e suas possíveis reações, analisamos quais formas de retaliação podem ocorrer em um ambiente desse tipo, considerando gênero. Realizamos pesquisa descritiva qualitativa. Entrevistamos 20 agentes do call center ( 9 homens e 11 mulheres) em Belo Horizonte, capital do estado de Minas Gerais, no Brasil. Todas as entrevistas foram transcritas na íntegra e os dados foram submetidos à análise do discurso (abordagem francesa). Os resultados mostraram que, neste caso, não houve diferença de gênero em relação às injustiças percebidas. Assim, os trabalhadores de ambos os sexos muitas vezes retaliam e consideram suas ações razoáveis.

Palavras-chave: Retaliação, gênero, call center.

\section{Introduction}

Call centers are part of the current circumstances of productive restructuring, which emphasizes a "new work morphology" (Antunes, 2009) characterized by greater flexibility and deregulation of jobs. "Within a call center, the time of the line workers is evaluated and controlled in a rigorous way, with pauses and schedules carefully established. The pace of work is intense, requires fast procedures and call handling and differentiated skills in terms of listening, speaking, logical reasoning etc." (Paiva, Dutra, Santos, \& Barros, 2012, p. 527). This implies the development of new people management approaches in the productive sphere, but at the same time coexisting with Fordist practices, which remain present in certain service industries, such as call centers (Antunes, 2012).

Professional relationships in service industries tend to be unstable and temporary (Paiva, Dutra, \& Luz, 2015; Cappelli \&
Keller, 2013); there are weaker legal protections and lower wages, which are characteristic of precarious (Mendes, Vieira, \& Morrone, 2009) and unskilled jobs (Parker, Johnson, Collins, \& Nguyen, 2013). Call center agents suffer from excessive pressure to obtain results (Paiva et al., 2015). They work parttime hours during which a high increase in pace negatively impacts their activity. Their managers rigidly monitor their breaks and tasks. The "invisible" nature of this job tends to lead to positions being filled by different social groups, usually those excluded and/or discriminated against by the job market such as youth, blacks, women, and homosexuals (Ramarajan \& Reid, 2013); these groups deviate from the job market stereotype: heterosexual "white men employed in manufacturing" (Eccel \& Grisci, 2011, p. 61).

Due to these working conditions, physical, mental, and emotional health problems have been increasingly observed in these employees (Antunes, 2012). Although they interact 
directly with customers - which is often emotionally taxing (Gabriel \& Diefendorff, 2015) - they are underappreciated and the first to be laid off when the organization they work for faces hard times (Paiva et al., 2015).

Daily life in the organization allows for several interpretations regarding what happens in the company; value judgments inform such of those understandings. Every day, employees must deal with situations that (from their perspective) reveal various forms of inequality, resulting in mistrust, fear, and anguish (Gomide-Junior \& Siqueira, 2008). In fact, these inequalities can be understood as differences in the way people are treated based on rules that workers consider inappropriate (procedural justice), or a lack of equal treatment regarding access to resources (distributive justice). Perceptions of fairness, as well as their consequences in terms of retaliation, may vary according to cultural dimensions. For example: at the national level, to aspects related to collectivism and power distance (Fields, Pang, \& Chiu, 2000); at the organizational level, to the civility of the worker-subject; and, at the individual level, to self-control (Lian et al., 2014), (dis)trust, (Chan \& McAllister, 2014), courage or fear (Chan \& McAllister, 2014; Koerner, 2014), and even to physical issues such as sleep deprivation (Christian \& Ellis, 2011).

In reaction to perceived unfairness at work, workers may strike back, notwithstanding their hierarchical level, or whether they perform managerial functions (Creary, Caza, \& Roberts, 2015). Indeed, they might behave subtly or aggressively against the organization or their colleagues (Mendonça, 2008). Strictly speaking, such retaliation may also be considered one of the possible confrontation or defense strategies against suffering as outlined by Pagès, Bonetti, Gaulejac and Descendre (1987) and Lima (1996). However, is this behavior prevalent and independent of a worker's gender? In other words, the question that guided the study presented here was: How are related retaliation and gender in a call center? Therefore, the general objective of this study was to analyze what forms of retaliation can occur in such an environment by considering gender.

The relevance of our study lies in situations at a call center that were seen as unjust or stressful by the agents, who may react differently, especially considering how some personal attributes might influence their reactions. Indeed, variations in gender, religious or sexual orientation, age group, skin color, and people with disabilities, among others, could imply diverse revengeful attitudes and behaviors. After all, "in organizations, women, blacks, obese people, those with special needs, and homosexuals are subject to discriminatory practices" (Irigaray, 2008, p. 6), or even to more physically and symbolically violent practices (Misoczky, Camara, Cerqueira, \& Coto, 2012) that employees usually believe are unfair and therefore deserving of retaliation.

Gender differences have been among the most studied kinds of disparities for decades; a consensus has developed that they are a historical, political, and culturally built phenomenon, sometimes underestimated, sometimes exaggerated by society, and especially by organizations (Alvesson \& Billing, 1997). In any case, sensitivity to this theme has been growing in business schools (Sipe, Larson, McKay, \& Moss, 2015), perhaps pointing to a less discriminatory future, both in terms of wages and career since the so-called "glass ceiling" is still a reality, in Brazil (Carvalho-Neto, Tanure, \& Santos, 2014; Queiroz, Rego, \& Irigaray, 2014; Lima, Carvalho-Neto, Lima, Tanure, \& Versiani, 2013) as well as in other countries (Hoobler, Wayne, \& Lemmon, 2009).

Given the growing precariousness of jobs in contemporary society, especially in outsourced companies (Mendes et al., 2009; Paiva et al., 2015) such as call centers, a closer look into their complex reality is necessary (Mendes et al., 2009; Paiva et al., 2015), as well as the perceptions of call center agents on their work conditions.

Harmful or "uncivilized" behaviors usually have negative impacts on both people and an organization's outcomes (Porath \& Pearson, 2012), even when we consider mediating aspects of this relationship, such as power distance and work satisfaction (Lin, Wang, \& Chen, 2013).

In addition to the introduction, this paper is organized into five sections. The next part introduces the theoretical background, while the third discusses the methodology (qualitative approach, using interviews and discourse analysis). The fourth section presents the results, and the fifth interprets the findings based on the theoretical context. As the main contribution of the study, we highlight the non-differentiation of gender in the aspects considered regarding the retaliation in the work environment approached, contrary to the literature.

\section{About retaliation in the workplace}

Dysfunctional behaviors at work, such as retaliation, have been described as socially disapproved acts against an organization or its members (Mendonça \& Tamayo, 2004). As a matter of fact, retaliation has an instrumental perspective, for employees may use it as a means to seek restoration of justice through actions that compensate for perceived harms or losses, which are due to the employee's belief that he/she has been treated unfairly.

In this research, we understand retaliation as a behavior that arises due to a perception of injustice in a person's surroundings, from which he or she develops ways of reacting (Skarlick \& Folger, 1979) and releasing anger (Weiss, Suckow, \& Cropanzano, 1999). Retaliation is also a response to perceived unfairness and discrimination (Mendonça \& Tamayo, 2004). Indeed, discrimination leads to tension, which the individual strives to discharge by reestablishing equality (Irigaray, 2008). This can happen in several ways, such as looking for compensation, striking back at the tormentor, or causing distorted views of the situation, among others possibilities (Gomide-Junior \& Siqueira, 2008). The intensity of the retaliation might also vary according to the degree of alleged (un)fairness (Adams, 1963).

Previous studies suggest that such behavior can also occur when employees have strained relationships with their 
managers (Townsend, Phillips, \& Elkins, 2000). They may perceive this relationship as fair or unfair (Charnnes \& Levine, 2010) based on what happens in the workplace.

Retaliation is becoming more common in organizations, mainly due to the fact that inside them, a complex network of relationships is marked by competition, individualism, conflict, and consequently, psychosocial problems (Assmar, Ferreira, \& Souto, 2005). Among employees, discrepancies between their own abilities and the demands of their physical and social work environments have led to experiences of unfairness regarding what transpires around them (Assmar, Ferreira, \& Souto, 2005). As these attitudes and perceptions recur, the retaliation assumes characteristics that fit the context in which it happens (Mendonça \& Mendes, 2005).

Organizational retaliation is defined as behaviors influenced by the personal attributes of the organizational actors involved. This conduct may occur subtly or ostensibly (i.e., aggressively) based on the employee's view of having been wronged; the employee targets colleagues or the organization itself (Mendonça, 2008). His/her actions range from verbal aggression, practical jokes that ridicule a coworker, dysfunctional communication (gossip), to omissions and boycotts (Mendonça \& Tamayo, 2003, 2004; Paiva \& Leite, 2011).

A retaliatory attitude or the inclination to strike back consists of two components. The first element is affective and regards indignation, a belief that one has suffered from injustice. This outlook breeds resentment, disappointment, and contempt (Mendonça, 2008), depending on how often the subject feels indignant when faced with injustices committed against him or herself or others. The second aspect is conative and relates to an individual's conscious tendency to behave in a specific way, such as to mirror the organization's (unfair) inclination (Mendonça, 2008), that is to say, practically acting in the same way that it disagrees and that it judges unfair or inadequate.

We can look at two facets to assess the actual retaliatory behaviors of an organization's members: (1) The perceptive dimension, which relates to one's view of the frequency with which people in an organization behave in a given manner when they feel wronged at work; and (2) The evaluative dimension, which reveals the degree to which an individual thinks it is reasonable that others strike back when faced with unfairness on the job (Mendonça, 2008). These two dimensions are interrelated, since it is not reasonable to think of retaliating something that is not perceived in the environment; on the other hand, depending on the perceived injustice and the degree of discomfort it creates, the subject can effectively behave retaliatorily, counterproductively.

Retaliatory attitudes can also be considered mechanisms of defense or resistance, and a way to overcome a disagreement. Retaliation can be either positive or negative for the subject; it reestablishes a sense of equality and balance between what one invests in a job and what one receives in return (Mendonça \& Mendes, 2005). Revengeful actions tend to protect the employee from suffering, although this probably presages a decrease in his/her performance. If internal balance returns, the worker's defenses will also improve, creating more resilience in situations of adversity resulting from exposure to unfairness.

Therefore, retaliation is a strategy on the part of the employee, manifested in different ways according to individual differences and the unique circumstances of the workplace (Mendonça, 2008).

\section{About gender and retaliation in the workplace}

It is possible to theorize that personal attributes such as gender (in addition to factors such as sexual or religious orientation, age group, skin color, and special needs) may imply different retaliatory feelings and behaviors.

The concept of manliness has historically been built upon and associated with values such as "courage," "autonomy," "ability," "adventure" and "group solidarity" (Carrigan, Cornell, \& Lee, 2002, p. 75). In this sense, the concept of male hegemony rests on how a particular group of men - Caucasian, heterosexual, and with access to capital - takes possession of privileged positions of wealth and power in the social corpus, and how this group is able to legitimately maintain the social relationships that create and support its control. This descriptive gender stereotype differs from a prescriptive gender stereotype, since the former refers to beliefs "about what men and women are like" and the second creates "expectations for what men and women should be like, dictating which attibutes and behaviors are acceptable and which ones are "off limits"” (Caleo, 2016, p. 1423).

Regarding the workplace, previous studies suggest that compared to men, women display stronger standards of double bonds with their jobs; that is, a greater commitment to both the organization and their occupation (Bastos, Correa, \& Lira, 1998; Machado, 1999). Such research has also detected complaints, dissatisfaction, insecurity, and distress among women regarding their work environments and professional relationships (Carvalho, Carvalho, \& Santos, 2002). Thus, does gender affect the form that retaliation takes?

In spite of revanchist behaviors are receiving increasing attention from researchers worldwide (Aquino, Tripp, \& Bies, 2001), in fact, counterproductive work behavior has been largely ignored, but research findings suggest that women are less likely to engage in such behavior that compromises personal and organizational outcomes just like their career $(\mathrm{Ng}$, Lam, \& Feldman, 2016). Other studies on the consequences of allegations of illegal behavior have indicated differences between genders - including retaliation against whistleblowers - and other diversity aspects, such as ages or age groups. This denotes the extent to which gender studies imply in terms of the power relations that effectively reflect. (Liyanarachchi \& Adler, 2011; Rehg, Miceli, Near, \& Scotter, 2008).

These all are the reasons why the data collected will be analyzed according to the elements and dimensions mentioned above. 


\section{Methodological procedures}

Throughout our study, we have been aware that our research strategy would not allow us to remain neutral or autonomous; however, we strove to maintain impartiality by keeping a distance from the study objects (i.e., bracketing). We followed Bourdieu's (2007) suggestions and avoided confusing our subjectivism (value judgments) with the subjectivism of the research objects (individuals, groups, and socio-cultural systems).

For the interviews, Goldenberg's (2000) reflections were why we adopted a script compatible with a focused, semi-structured interview. We told the respondents the goals of the study $a$ priori, and preserved their anonymity and confidentiality.

We conducted our empirical research at a call center company in Belo Horizonte in the Brazilian state of Minas Gerais, which was characterized as the unit of analysis of the case study (Collis \& Hussey, 2005). We interviewed 20 agents from the following departments: passive (a sector where agents only receive phone calls from customers) and active (a sector in which agents call customers to sell products/services). Using the snowball method, we started the interviews by personally contacting various subjects; each one referred us to other possible respondents (Turato, 2003). We ended the interviews based on data saturation criteria; that is, we conducted interviews until reaching "theoretical saturation," which occurs when adding new interviews does not result in a significant increase in collected information (Gil, 2006). For this study, saturation happened on the $20^{\text {th }}$ interview.

All participants consented to the interview being recorded and performed according to a semi-structured script, which helped us explore in-depth questions related to retaliation within the company. This allowed us to gather details about the respondents' thoughts, actions, and feelings (Collis \& Hussey, 2005).

We fully transcribed all interviews, which facilitated data analysis according to the French approach to discourse analysis. The option for this instrument is justified by the diversity of approaches and possible applications of this technique, specifically on the possibilities that this technique opens with regard to the syntactic processes of enunciation related to linguistics, to the ideological processes underlying the text related to class positions (Althusser), to the said and un-said (or implicit) processes of discursive practice (Foucault), and to the psychoanalytic processes related to the interests of desire (Lacan) (Silva, 2009). Hence, when considering the complexity of workplace relations in the call center, this method reinforced the analysis, allowing us to "study the different senses that words can describe according to those that use them and how they do so" (Pêcheux, 1990, apud Silva, 2009, p. 177). In the data analysis, we underlined the words that we identified as themes in the excerpts and italicized the words that we identified as figures.

\section{Findings and Discussion}

We sorted the data based on gender, focusing on the affective and conative elements of retaliation, in addition to its perceptive and evaluative dimensions.

Most of the interviewees were women (11 of them), under 25 years of age (15 of them), unmarried (16 of them), with incomplete higher education (11 of them), who worked less than 10 years (18 of them) and in the call center, specifically, less than 2 years ( 18 of them), in the morning shift (19 of them), receiving between 1 and 2 minimum wages (18 of them).

\subsection{Gender and elements of retaliation}

The affective element (Mendonça, 2008; Paiva \& Leite, 2011) in male discourse can be understood by looking at the following excerpt:

“Today I don't [feel appreciated] because I quit while doing my best. We, [or rather] I gave my best for over a year. In there, if you are not literally brown-nosing, then nobody has the opportunity to grow." (E5)

In this textual fragment we have identified 10 themes and 3 figures. The semantic approaches that we observed were "recognition at work" and "growth at work."

As for the elements underlying the semantic discourse, we noted that a lack of appreciation for employees leads them to forgo engaging in their tasks thoughtfully so as to be recognized (explicit from the passage: "I quit while doing my best"); this is opposed to the idea that increasing productivity leads to growth at work (this is implicit).

The main discourses that we identified concerned the "effects of unfairness on the individual" and "retaliatory attitudes in the organization." In a situation in which the agent performed his tasks at a superior level but the company failed to recognize or appreciate him, he deemed the situation unfair. As a result, he did not perform his activities with a high degree of productivity and expressed dissatisfaction with the organization.

Regarding an excerpt from a female about the affective element (Mendonça, 2008; Mendonça \& Tamayo, 2003, 2004; Paiva \& Leite, 2011), our analysis is similar to the previous one:

"Yes, I have had [an attitude of contempt before]. I am an employee with perfect attendance... I needed (...) one weekend in which they would not be able to operate on Sunday, because there was scheduled maintenance in the building and I was taking a course on Saturday. It was a whole day affair; there was no way I could work Saturday. On Sunday they refused to let me negotiate. I had not missed one day at the company. I had been working there for almost one-and-a-half years straight and like that, when I needed the company to meet my needs most, the company didn't recognize them." (E9)

In the excerpt above, we identified 17 themes and 8 figures. We pinpointed the following semantic approaches: "rules and regulations at work" and "work relationships." 
Regarding the elements underlying the semantic discourse, the agent thought that she was abiding by the company's rules and displayed the behavior expected of her (explicit from the passage "I am an employee with perfect attendance (...) I had not missed one day at the company"), as the prescriptive female stereotype (Caleo, 2016). Thus, she believes it is possible to negotiate days off when necessary. Such an outlook normally leads to one feeling satisfied with one's workplace (implicit). However, the company was not flexible when it came to negotiating days off (explicit in the passage "when I needed the company to meet my needs most, the company didn't recognize them"), leading the worker to have an attitude of contempt (explicit in the passage: "yes, I have had"). Faced with the perception of an unjust situation, the agent retaliated against the company (presupposed).

The principal discourses we identified were the same from the previous analysis ("effects due to unfairness toward the individual" and "retaliatory attitudes in the organization"), bolstered by other excerpts in which we could see a high frequency of pay docking and reprimands. The employee in the excerpt above expressed hatred for the organization and people who worked there by assessing behavior that she considered reasonable. Such behavior occurs via a give-andtake relationship in which it is hypothetically possible for the agents to invest in the organization; for instance, it includes increasing their commitment to the call center.

Regarding the conative element (Mendonça, 2008; Mendonça \& Tamayo, 2003, 2004), we selected the following excerpt from a male respondent:

"For nearly a year-and-a-half, I never came in late. When I asked to take a vacation, they didn't even want to give me one! Then I started to come in late almost every day. I didn't use to [miss work], but, lately, I have missed a lot. I might wake up and say: 'Oh, I won't go to work today, I am tired and will stay at home." (E5)

We identified the main themes and figures, which lead us to pinpoint the following semantic approaches: "unfairness in the proceedings" and "job dissatisfaction."

Thus, we lined up the following underlying elements of the discourse: little or no absenteeism and tardiness by the agent at the beginning of his tenure with the company (explicit in the passage: “I never came in late," “I didn't use to [miss work], but lately, I have missed a lot"). This is in opposition to the agent's increased absenteeism and tardiness (explicit), compounded by the perception of unfairness (presupposed), which justifies retaliation (also presupposed).

We identified the following primary discourses: "organizational exchange relations," "human behavior in organizations" and "retaliatory attitudes." The agent started to miss work and arrive late with certain regularity because he felt he was wronged when he considered his exchange relations with the organization. He believed that this relationship was neither uniform nor reciprocal, and that what he gave to the organization was not returned to him to the same extent when compared with what the organization gave him. We added other excerpts to this analysis in which the respondent demonstrates that his/her constant absences from work are his/her way of trying to establish a balanced relationship between him/herself and the company, which is embodied in the management. This conjecture supports the ideas of Townsend et al. (2000), as well as Charnnes e Levine (2010), since the employee believes it is fair to display such behavior in order to respond to how the company treated him/her.

In the female discourses, the conative element (Mendonça, 2008; Mendonça \& Tamayo, 2003, 2004) appears in a similar manner:

"Oh, I was outraged! I was outraged... then I started calling in sick, I started dropping calls, I started to be rude to customers, who didn't have anything to do with the situation, but ended up being involved either directly or indirectly..." (E11)

The main themes and figures we observed in the excerpt allowed us to line up two semantic approaches: "perception of unfairness at work" and "dissatisfaction at work."

Regarding the elements underlying the discourse, the perception of unfairness at work caused the employee to feel outrage (explicit and repeated in the word "outraged"), which in turn caused her to have a retaliatory attitude toward the organization (explicit: "then I started calling in sick, I started dropping calls, I started to be rude to customers"). This is opposed to situations of organizational fairness, which do not cause retaliatory approaches (implicit) and positively influence people's behavior in an organization (presupposed).

The main discourses we identified were the same as in the previous analysis ("organizational exchange relations," "human behavior in organizations," and "retaliatory attitudes").

In addition to the previous excerpt, other women indicated that female agents are aware of retaliatory behaviors regarding the unfair way in which the company treats its personnel (the conative component of retaliation), and that female agents perceive outrage as much as their male peers (the affective component of retaliation), that is, as something not "off limits" (Caleo, 2016).

“Then I went and got a sick note! I couldn't do anything if he [my colleague] didn't care [about me]...because you try to help others in order to receive help (...) My colleague, whom I just mentioned, went there with me and got a sick note. I got ten [days], and he got fourteen! Then, to escape that, we missed work." (E12)

This respondent also indicates that calling in sick was a way of reacting to the lack of support or cooperation on the part of the organization, as well as avoiding conflict with the company ("then, to escape that, we missed work"). This demonstrates one of the strategies developed by the workers, which supports the hypotheses of Pagès et al. (1987) and Lima (1996).

\subsection{Gender and components of retaliation}

Concerning the perceptive component (Mendonça, Pereira, Tamayo, \& Paz, 2003; Mendonça, 2008), we selected the following excerpt from a male participant: 
"Yes, [there is unfairness] (...) the girl worked two straight Sundays and, also, in her case, she was harassed to the point that she had to say she had a hemorrhoid problem. I think this is not fair. A person has to explain to the company why the toilet break counts as an extra personal break. It is a break that the company has to pay for, but she doesn't have a legal reason to support her demand (...). I feel a little powerless, because my wish would be to fix that..." (E3)

In the previous passage, we observed several themes and figures, which led us to identify 3 semantic approaches: "perception of unfairness," "dissatisfaction at work," and "work relationships."

As for the elements underlying the discourse, the agent discerned an unfair situation happening with his peer (explicit in the passage: "the girl who worked two straight Sundays (...) she had to say she had a hemorrhoid problem"). He perceives the company's actions as unfair, although legal (explicit in the passage: "I think this is not fair (...) she doesn't have a legal reason to support her demand"), and feels unable to help solve the problem at hand ("I feel a little powerless, because my wish would be to fix that"). This is opposed to a situation of fairness and legality, which results in no retaliatory circumstances arising (implicit) and allows employees to be satisfied (presupposed).

The main discourses that we recognized were "organizational fairness," "organizational diagnosis" and "retaliation". Based on the views of employees and their colleagues, when the company treats one of them unfairly, the others notice the situation and may express indignation due to feeling helpless since they cannot solve the problem. Calling in sick on purpose, failing to do one's best work, and looking for ways to be fired as retaliatory mechanisms (explicit) are common responses in the face of conditions that are seen as unjust (implicit). This compares to fairer treatment within an organization whereby absenteeism, turnover, and mistakes are avoided in the productive process (implicit). In principle, such attitudes and behaviors harm both the company and the worker; the company's public image may suffer if there is a large number of layoffs without legal reasons.

Women also assessed the perceptive component (Mendonça et al., 2003; Mendonça, 2008) in a similar way, as we can see in the following excerpt:

"I am like that, burned... I cannot take it anymore, and my colleague has even said 'I am being persecuted.' He told that to the doctor. (...) And she gave him a sick note." (E12)

From the themes and figures observed, we identified the semantic approaches "perception of unfairness," "dissatisfaction at work," and "relationships at work."

Regarding the elements underlying the discourse, the agent heard how her peer interpreted a situation of being wronged at work (explicit in the passage: "I am being persecuted"). What she does in regard to this perception of unfairness (explicit in the passage: "he told that to the doctor (...) and she gave him a sick note") is opposed to the fact that a situation that is considered fair would not cause the agent to go to the doctor and ask for a sick note (implicit); equal treatment could decrease the level of absenteeism in the company (presupposed).

The main discourses we observed included "organizational unfairness" and "retaliation." Besides persecution being considered wrong (from the analysis of the previous excerpt), it was verbalized in other excerpts that focus on its contribution to reduced loyalty between the employee and the company. Conversely, we easily identified the visibility of retaliations in the company in both directions; that is, from the employee to the company (via a disrupted productive process) and from the company (represented by an employee's immediate superiors) to the employee. In these excerpts, we observed emotions (Weiss et al., 1999) such as anger and outrage.

The last dimension that we saw in the excerpts was the evaluative component, distinguished by gender. Note the excerpt below, which we transcribed from the speech of a male respondent:

"In terms of getting a sick note, saying that one is tired (...). Yes, I think it is totally fair. When you feel this weariness, then you end up really having a stress load that will influence your health, your family life, and the people in your daily life outside the company, whether you want it or not. Then, in a way, I think it is totally fair." (E10)

We identified the themes and figures, as well as the following semantic approaches: "organizational stress" and "exchange relations in the organization."

In light of the discourse's underlying elements, behaviors that do not benefit the organization (explicit in: "getting a sick note, saying that one is tired") are deemed reasonable (explicit and repeated in: "totally fair") due to one being sick of dealing with the organization. In turn, this causes stress (explicit in the passage, "When you feel this weariness" and "you end up really having a stress load"), versus a more evenhanded relationship, which creates less tension (implicit) and would help prevent retaliatory attitudes among the agents (presupposed).

Furthermore, a more balanced relationship would avoid the possibility of the perceptive component of retaliation not being seen as favorable by the remaining components of the company (presupposed). Therefore, the predominant discourses are "human behavior in organizations," marked by relationships of cause and effect, as well as "organizational stress" and "retaliation" in the organizations. It is also notable that, via their relationships with peers and the organization, employees assess what kind of behavior is reasonable. That is, when other agents considered their relationship with the company to be unfair, they tended to express a sense of support and belonging or, on the contrary, sadness and disappointment, as well as a level of accommodation that breeds dissatisfaction and rebellion. Thus, we can see the contradictions involved in this process. 
A similar analysis can be seen in the excerpt below:

"Oh, I think it is fair, more than fair that a person has the right... to present a defense, you know? (...) to prove she did not do that. Then, it's more than fair, right? Having the company listen to the employee regarding what happened." (E9)

The major themes and figures that we observed were: I think, fair, has, right, prove, she, did not, do, yes, listen to (10 themes), me, person, she, company, and employee (5 figures). The semantic approach of "organizational exchange relations" was once again apparent, highlighting that - in terms of the elements underlying the discourse - the agents view retaliatory attitudes as reasonable (explicit in: "Oh, I think it is fair, more than fair") through a perception of organizational unfairness. We can see this when the company does not listen to its employees or give them leave (explicit in: "a person has the right... to present a defense... to prove she did not do that (...) Having the company listen to the employee"). This is contrasted with the possibility of the call center communicating with its employees, which minimizes the development of a retaliatory stance (implicit).

The discourses of "human behavior in organizations" and "retaliation in organizations" were present in excerpts from female respondents, as well as the negative feelings displayed by men. However, what women reported included moral harassment through threats to their permanence in the company. As shown in the excerpt below, an employee retaliated with the "sick note" strategy. It is interesting that these kinds of reports were more often present among women.

"Well, it's fair! The person is threatening me with not paying my salary. Will I will keep showing up without being paid? I will get a sick note! We do get sick notes! Sometimes, a sick note isn't because you are just skipping work, but because you are being threatened in your workplace. Got it? Or the person, either she will really change, because she will become afraid, or she will hurt you somehow until you lose your patience with her, until the manager loses patience with her and fires her. This is very unlikely. What else to do? Anybody would get a sick note." (E12)

The discourse analysis of male and female respondents revealed similarities regarding feelings of unappreciation, a lack of interest in the tasks performed, quitting, discouragement, a lack of perspective on professional growth, changes in productivity, absenteeism, stress, and other health problems in the face of allegedly unfair situations in the workplace.

There are also the relatively frequent missed days and tardiness, both perceived as a way of obtaining justice when the organization treats its employees disrespectfully. The subjects felt that what they gave to the organization was not returned to them in equal measure, thus, retaliating is a behavior considered necessary to reestablish their integrity, that is, within such "limits" (Caleo, 2016).

Hence, they sought to establish a balance in their relationship with the company. On the other hand, when the company acted unfairly toward one of its employees, this caused the other agents to notice the situation and to express outrage regarding their own limited ability to respond; they believed they could not interfere or help solve the problem. It is particularly apparent that the parties involved in organizational relationships make judgments based on fairness. That is, when other agents considered their relationships with the call center unjust, they tended to display feelings of support and belonging that they demonstrated via deliberate acts of retaliation, whether through absenteeism (using sick notes), decreasing productivity (taking less calls, dropping calls), or quality (offering poor service to customers).

Regarding gender, we did not observe differences in the answers or behaviors of either the male or female respondents. This highlights the fact that both genders retaliated against the organization when they felt they were being treated poorly, and considered such behavior to be reasonable.

\section{Conclusions}

Our analysis of the interviews, the excerpts we chose, and our careful examination of them led us to conclude that the interviewed agents, regardless of gender, have experienced several incidents of unfairness; these occurrences arose from a productive process meant to obtain the most benefits from each worker's efforts in the least possible amount of time, clocking each call and break. This process splits work to such a degree that relationships based on fellowship - which can develop and grow among coworkers - become strained. Alternatively, such relationships only seem possible when based on common resistance strategies (collective and individual) against this process and all the actors that benefit from it: coworkers, managers, and the company itself. Employees found inequalities in both the formal rules of the company and in access to resources, thus adding procedural to distributive injustice.

The analysis of retaliatory attitudes revealed that both male and female participants expressed various reactions (subtle, overt, and aggressive) when they perceived injustices. The affective component was present in the excerpts, as both genders manifested indignation via the perception that unfairness existed within the organization. Likewise, we also observed the conative component, which refers to subjects' conscious inclination to respond in the same way in which the company treats them, especially by dropping ongoing calls, reducing the pace of work, ignoring the script prescribed for customer support calls, and taking sick leave. The company seems to have few options to solve the problem of retaliation besides increasing pressure on the workers and trying to implement internal motivational campaigns. Excerpts indicate that employees who do not miss a certain number of days a week receive prizes, which somehow legitimizes the way in which retaliation may occur, without major legal consequences for the employee.

Our analysis of the perceptive dimension indicated that notwithstanding gender, respondents often used the 
mechanisms cited above. Such behavior was nothing new; on the contrary, the participants seemed to count on the possibility of remaining with the company and continuing to work.

Concerning the evaluative dimension, the results showed the prevalence of a common perception that it is fair for people to act in a revengeful way in response to unfairness suffered or observed at work. We thought the amount and variety of coping and defense strategies developed by the agents were surprising; no single narrative suggested embarrassment or regret from paying the organization back in the same "coin" with which both male and female agents believe they were treated.

These workers are deeply affected by the stressful conditions of the call center, making it essential for them to adopt defense mechanisms in order to maintain psychological balance. Some subjects have already displayed signs of failing health such as high stress, depression, and use of medication.

It is important to list the work conditions high pressure and causes of stress, which tend to cause the agents to strike back. The agents suffered from high pressure to meet targets, an "infinite" call load, breaks and tasks rigidly controlled by management, maltreatment, peer competition, moral harassment, low wages, a lack of recognition, underappreciation of their work, unfairness in the distribution of wages, holidays, and vacations, and injustice in terms of decision-making.

Based on this study, it is also possible to reflect on the increased flexibility and deregulation of labor relations due to outsourcing. As mentioned in the literature, the new format of management in the workforce profoundly affects work conditions; in turn, this may cause dissatisfaction, a perception of unfairness, and retaliation within companies. All this may harm companies' outcomes, as we observed in this study.

Regarding retaliatory attitudes and behaviors, we identified several possible expressions such as truancy, unnecessary sick leaves, abusing supervisors or customers, dropped calls, legal actions against the company or management, and embarrassing practical jokes played on coworkers. We observed a vicious cycle: in some cases, agents' retaliatory attitudes and behaviors against managers prompted the same negative reactions from the management against the agents. These cycles help spread dissatisfaction throughout time and across social networks within the organization.

It is noteworthy that each agent evaluated their peers' reactions to situations of unfairness distinctly. Some supported them, others blamed them, while others remained neutral; however, every respondent either retaliates or has retaliated in the call center. This fact reinforces the perception that individuals are different, no matter how the organization wants or tries to lump them together through the policies and practices of people management. The agents began working at the company with a consolidated, or evolving, identity, with cultural and historic origins that will influence their views of what is fair in their workplace.

However, it is important to stress that every initiative pointed out by the agents was focused on rule compliance (that is, on applying the organization's rules) rather than changing the organization's intrinsic problems. Thus, it is necessary to reflect on the fact that most agents do not question the reasons behind the company's rules, but rather which rules will be applied, in addition to where, with whom, when, and how.

To a certain degree, these points of passivity are becoming a hurdle for collective demands within the call center, whether they relate to better work conditions or gender issues. Turnover, individualization, competition, and the fragility of the workers' union hamper the call center's collective demands, which perhaps would be more likely to change the logic behind the rules, rather than merely focusing on applying them. This is the main motive for striking back, as reported by the respondents. Hence, the results confirm that there are ways of defending oneself against injustice and the very format of the productive process; the questions that the participants ask themselves also verify this, even if they behave based on adaptive actions rather than transformative ones.

Concerning the study's limitations, the fact that we conducted it at just one call center should be highlighted. We must analyze similar organizations, both in the city of Belo Horizonte as well as at other sites in Brazil. It is possible to amass a quantity of data that would certainly make theoretical-conceptual progress possible; this would allow us to make comparisons and perhaps generalizations. Other outsourcing companies from the information technology (IT) sector could be contacted in order to compare opinions regarding work conditions and the perceptions of other types of workers who experience similar productive circumstances. Another suggestion would be to expand the data analysis to other positions within the call center; in our study, we only analyzed the views of the agents due to access restrictions imposed by the company.

Other aspects related to diversity could be approached, such as questions related to discrimination within organizations; for example, about sexual or religious orientation, skin color, age group, and special needs.

Our work opens up fertile ground for future research, both related to the central topics (retaliation and gender), as well as the industry under study (call center companies).

With respect to the methodology used, two limitations must be mentioned: first, the adoption of the case study precludes further generalizations; second, only one instrument of data collection (interviews) prompts the accomplishment of studies with greater sophistication in this sense, using inter- and intramethodological triangualizations, in order to deepen in the phenomena in focus, as well as broadening the scope of the study, based on complementary methods and techniques. 
We concluded that regardless of gender, the men and women we interviewed understand and deal with unfairness in a similar way, which is contrary to the gender literature. Thus, in the practical field of organizational daily life, greater care is suggested by organizations with the issues addressed here, since the indignation with injustices and retaliation constitute a reality, regardless of gender. Their voices may be different, but their excerpts revealed similar attitudes.

\section{References}

Adams, J. S. (1963). Towards an understanding of inequity. Journal of Abnormal and Social Psychology, 67(5), 422-436.

Alvesson, M., \& Billing, Y. D. (1997). Understanding Gender and Organizations. London: SAGE.

Antunes, R. (2009). O trabalho, sua nova morfologia e a era da precarização estrutural. Revista Theomai, (19), 47-57.

Antunes, R. (2012). A nova morfologia do trabalho no Brasil. Reestruturação e precariedade. Revista Nueva Sociedad, (232), 3-4.

Aquino, K., Tripp, T. M., \& Bies, R. J. (2001). How employees respond to personal offense: the effects of blame attribuition, victim status, and offender status on revenge and reconciliation in the workplace. Journal of Applied Psychology, 86(1), 52-59.

Assmar, E. M. L., Ferreira, M. C, \& Souto, S. O. (2005). Justiça organizacional: uma revisão crítica da literatura. Psicologia: Reflexão $e$ Crítica, 18(3), 443-453.

Bastos, A., Correa, N., \& Lira, S. (1998). Padrões de Comprometimento com a Profissão e a Organização. Proceedings of the Encontro da Associação Nacional de Pós-Graduação e Pesquisa em Administração (ANPAD), Foz do Iguaçu, PR, Brasil, 22.

Bourdieu, P. (2007). A Dominação Masculina. Rio de Janeiro: Bertrand Brasil.

Caleo, S. (2016). Are organizational justice rules gendered? Reactions to men's and women's justice violarions. Journal of Apllied Psychology, 101(10), 1422-1435.

Cappelli, P., \& Keller, J. R. (2013). Classifying Work in the New Economy. Academy of Management Review, 38(4), 575-596.

Carrigan, T., Cornell, B., \& Lee, J. (2002). Toward a New Sociology of Masculinity. In: H. Brod (Ed.). The Making of Masculinities (pp. 37-54). Boston: Allen and Unwin.

Carvalho, J., Carvalho, M., \& Santos, L. (2002). Novas bonecas feitas de velhos retalhos: investigando medos, ansiedades e inquietações das mulheres nas organizações. Proceedings of the Encontro da Associação Nacional de Pós-Graduação e Pesquisa em Administração (ANPAD), Salvador, BA, Brasil, 26.

Carvalho-Neto, A., Tanure, B., \& Santos, C. M. (2014). Orgulho e Preconceito além do Teto de Vidro: o tipo psicológico das executivas brasileiras. Revista de Ciências da Administração, 16(39), 210-223.

Chan, M. E., \& McAllister, D. J. (2014). Abusive management through the lens of employee state paranoia. Academy of Management Review, 39(1), 44-66.

Charness, G., \& Levine, D. I. (2010). When Is Employee Retaliation Acceptable at Work? Evidence from Quasi-Experiments. Industrial Relations, 49(4), 499-523.

Collis, J., \& Hussey, R. (2005). Pesquisa em Administração. Porto Alegre: Bookman.

Creary, S. J., Caza, B. B., \& Roberts, L. M. (2015). Out of the box? How managing a subordinate's multiple identities affects the quality of a manager-subordinate relationship. Academy of Management Review, 40(4), 538-562.

Christian, M. S., \& Ellis, A. P. J. (2011). Examining the effects of sleep deprivation on workplace deviance: a self-regulatory perspective. Academy of Management Journal, 54(5), 913-934.
Eccel, C. S., \& Grisci, C. L. I. (2011). Estudos de gênero nas organizações: implicações teórico-metodológicas. Cadernos Ebape.Br, 9(1), 57-78.

Fields, D., Pang, M., \& Chiu, C. (2000). Distributive and procedural justice as predictors of employee outcomes in Hong Kong. Journal of Organizational Behavior, 21(5), 547-562.

Gabriel, A., \& Diefendorff, J. (2015). Emotional labor dynamics: A momentary approach. Academy of Management Journal, January, 1-52. Retrieved from http://amj.aom.org/citmgr?gca=amj\%3Bamj.2013.1135v1, doi:10.5465/amj.2013.1135.

Gil, A. C. (2006). Métodos e Técnicas de Pesquisa Social. São Paulo: Atlas.

Goldenberg, M. (2000). A arte de pesquisar: como fazer pesquisa qualitativa em Ciências Sociais. Rio de Janeiro: Record.

Gomide-Junior, S., \& Siqueira, M. M. M. (2008). Justiça no Trabalho. In: M. M. M. Siqueira (Org.). Medidas do comportamento organizacional: Ferramentas de diagnóstico e de gestão (pp. 247-263). Porto Alegre: Artmed.

Hoobler, J. M., Wayne, S. J., \& Lemmon, G. (2009), Bosses' perceptions of family-work conflict and women's promotability: Glass ceiling effects. Academy of Management Journal, 52(5), 939-957.

Irigaray, H. A. R. (2008). Discriminação por Orientação Sexual no Ambiente de Trabalho: Uma Questão de Classe Social? Uma Análise Sob a Ótica da Pós-Modernidade Crítica e da Queer Theory. Proceedings of the Encontro de Administração Pública e Governança, Salvador, BA, Brasil, 3.

Koerner, M. M. (2014). Courage as identity work: Accounts of workplace courage. Academy of Management Journal, 57(1), 63-93.

Lima, G. S., Carvalho-Neto, A., Lima, M. S., Tanure, B., \& Versiani, F. (2013). O teto de vidro das executivas brasileiras. Revista Pretexto, $14(4), 65-80$

Lima, M. E. A. (1996). Os Equívocos da Excelência. Petrópolis: Vozes. Lian, H., Brown, D. J., Ferris, D. L., Liang, L. H., Keeping, L. M., \& Morrison, R. (2014). Abusive management and retaliation: A selfcontrol framework. Academy of Management Journal, 57(1), 116-139. Lin, W., Wang, L., \& Chen, S. (2013). Abusive management and employee well-being: The moderating effect of power distance orientation. Applied Psychology: An International Review, 62(2), 308329.

Liyanarachchi, G. A. \& Adler, R. (2011). Accountants' whistle-blowing intentions: the impact of retaliation, age, and gender. Australian Accounting Review, 57(21), 167-182.

Machado, H. (1999). Tendências do Comportamento Gerencial da Mulher Empreendedora. Proceedings of the Encontro da Associação Nacional de Pós-Graduação e Pesquisa em Administração (ANPAD), Foz do Iguaçu, PR, Brasil, 23.

Mendes, A. M. B., Vieira, A. P., \& Morrone, C. F. (2009). Prazer, sofrimento e saúde mental no trabalho de teleatendimento. Revista Eletrônica de Ciência Administrativa, 8(2), 151-158.

Mendonça, H. (2008). Atitudes retaliatórias. In: M. M. M. Siqueira (Org.). Medidas do comportamento organizacional: Ferramentas de diagnóstico e de gestão (pp. 247-263). Porto Alegre: Artmed.

Mendonça, H., \& Mendes, A. M. (2005). Experiência de injustiça, sofrimento e retaliação no contexto de uma organização pública do Estado de Goiás. Psicologia em Estudo, 10(3), 489-498.

Mendonça, H., Pereira, C., Tamayo, A., \& Paz, M. G. T. (2003). Validação fatorial de uma escala de percepção de justiça organizacional. Estudos: Saúde e Vida, 30(1), 111-130.

Mendonça, H., \& Tamayo, A. (2003). Construção e validação de um instrumento para a Medida de Atitude em Relação à Retaliação Organizacional (MARO). Avaliação Psicológica, 2(2), 147-153.

Mendonça, H., \& Tamayo, A. (2004). Percepção de justiça e reações retaliatórias nas organizações: Análise empírica de um modelo atitudinal. Revista de Administração Contemporânea (RAC), 8(2), 117135. 
Misoczky, M. C., Camara, G. D., Cerqueira, P. R., \& Coto, G. C. (2012). Orientação sexual, classes sociais e territórios de resistência: os conflitos em torno do Centro Nova Olaria - Porto Alegre. Gestão e Sociedade, 6(15), 254-279.

Ng, T. W. H., Lam, S. S. K., \& Feldman, D. C. (2016). Organizational citizenship behavior and counterproductive work behavior: do males and females differ? Journal of Vocational Behavior, 93, 11-32.

Pagès, M., Bonetti, M., Gaulejac, V., \& Descendre, D. (1987). O Poder das Organizações. São Paulo: Atlas.

Paiva, K. C. M., \& Leite, N. (2011). Justiça no trabalho e atitudes retaliatórias: um estudo com servidores técnico-administrativos de uma instituição federal de ensino superior. Revista Gestão e Tecnologia, 11(1), 50-67.

Paiva, K. C. M., Dutra, M. R. S., Santos, A. O. \& Barros, V. (2012). Proposition of time perception inventory. In José António C. Santos, Filipa Perdigão \& Paulo Águas, Book of Proceedings of the TMS Algarve 2012: Human Resources, Business Ethics \& Governance (pp. 523-535), Faro: Universidade do Algarve.

Paiva, K. C. M., Dutra, M. R. S., \& Luz, T. R. (2015). Comprometimento organizacional de trabalhadores de call center. Revista de Administração da USP, 50(3), 310-324.

Parker, S. K., Johnson, A., Collins, C. \& Nguyen, H. (2013). Making the most of structural support: Moderating influence of employees' clarity and negative affect. Academy of Management Journal, 56(3), 867-892.

Porath, C. L., \& Pearson, C. M. (2012). Emotional and behavioral responses to workplace incivility and the impact of hierarchical status. Journal of Applied Social Psychology, 42(1), 326-357.

Queiroz, L. G. M., Rego, M. L., \& Irigaray, H. A. (2014). Os impactos de gênero, orientações sexuais e etnias nos papeis dos Gerentes de Projetos no Brasil. Revista de Gestão e Projetos, 5(1), 1-14.

Ramarajan, L., \& Reid, E. (2013). Shattering the myth of separate worlds: Negotiating non-work identities at work. Academy of Management Review, 38(4), 621-644.

Rehg, M. T., Miceli, M. P., Near, J. P., \& Scotter, J. R. (2008). Antecedents and outcomes of retaliation against whistleblowers: gender differences and power relationships. Organization Science, 19(2), 221-240.

Silva, R. A, L. (2009). Contribuições da abordagem francesa de análise do discurso nos estudos contemporâneos sobre Teoria Organizacional (TO). In: A. P. Carrieri, L. A. S. Saraiva, T. D. Pimentel, \& P. A. G. SouzaRicardo (Orgs.). Análise do Discurso em Estudos Organizacionais (pp. 173-184). Curitiba: Juruá.

Sipe, S., Larson, L., McKay, B., \& Janet Moss, J. (2015). Taking off the blinders: A comparative study of university students' changing perceptions of gender discrimination in the workplace from 2006 to 2013. Academy of Management Learning \& Education, June, 1-43. Retrieved from http://amle.aom.org/content/early/2015/06/24/amle.2014.0139.full. pdf + html?sid=d69d11f0-a933-4508-a114-05625715fb8d, doi:10.5465/amle.2014.0139.

Skarlicki, D. P., \& Folger, R. (1997). Retaliation in the workplace: The roles of distributive, procedural, and interactional justice. Journal of Applied Psychology, 82(3), 434-443.

Townsend, J., Phillips, J. S., \& Elkins, T. J. (2000). Employee retaliation: The neglected consequences of poor leader-member exchange relations. Journal of Occupational Health Psychology, 38(4), 457-463.

Turato, E. R. (2003). Tratado da metodologia da pesquisa clínicoqualitativa. Petrópolis: Vozes.

Weiss, H. M., Suckow, K., \& Cropanzano, R. (1999). Effects of justice conditions on discrete emotions. Journal of Applied Psychology, 84(5), 786-794.

Received: 07.12.2017

Revisions required: 25.03 .2018

Accepted: 15.04.2018 